\title{
Teaching International Students to Analyze Textual-Discursive Categories
}

\author{
Ivanna M. Fetsko ${ }^{1,}$, Ilona M. Novak ${ }^{2}$, Liubov M. Terletska ${ }^{3}$, Oksana H. Soshko ${ }^{4}$ Oksana A. Lytvynko \\ ${ }^{1}$ Department of Applied Linguistic, Ivan Franko National University of Lviv, Lviv, Ukraine \\ ${ }^{2}$ Department of Foreign Languages, KROK University, Kyiv, Ukraine \\ ${ }^{3}$ Department of Foreign Languages and Methods of Teaching, Borys Grinchenko Kyiv University, Kyiv, Ukraine \\ ${ }^{4}$ Department of Foreign Philology and Translation, Kyiv National University of Trade and Economics, Kyiv, \\ Ukraine \\ ${ }^{5}$ Department of Foreign languages, Sumy National Agrarian University, Sumy, Ukraine \\ *Correspondence: Department of Applied Linguistic, Faculty of Philology, Ivan Franko National University of Lviv, \\ 1 Universitetska Str., room 233, 79001, Lviv, Ukraine. E-mail: ivannafecko@gmail.com
}

Received: September 29, 2021

Accepted: October 26, $2021 \quad$ Online Published: November 12, 2021

doi:10.5430/jct.v10n4p34

URL: https://doi.org/10.5430/jct.v10n4p34

\begin{abstract}
The purpose of the study is to identify how the course that covers the components of the ten-stepwise approach to discourse analysis of political texts helps international students study the political meanings in Ukraine. The study used the structured observation method to collect rather quantitative than qualitative data and observers' reports on the sampled students' performance in the in-class and out-of-class assignments. It also used discourse analysis awareness test, observation report checklist, and assessment checklist to yield the quantitative data. The course that is based on the ten-stepwise approach to discourse analysis of political texts proved to raise the students' overall awareness of analysis of textual-discursive categories and fosters their skills of both discourse analysis and technical skills to use the NVivo 12 software tool. The results of the Discourse Analysis Awareness Test showed that the sampled students' awareness of discourse analysis was generally good. The mean values varied between 0.643 and0.857, which corresponded to 65-85 grades ECTS. The analysis of the observation reports showed that the five most frequent words used in the corpus of the observation reports of seven experts were as follows: students, contributed, equally, succeeded, managed. All of them evoke a positive idea and feeling and reveal success in meeting goals. The quotes yielded from the reports implied that the course sessions were engaging, challenging, and fruitful in terms of learning how to analyze textual-discursive categories found in political texts. The descriptive statistics drawn from the observation checklist and presented by course topic showed that the observers' mean values improved throughout the course sessions that meant that the students progressed in the discourse analysis.
\end{abstract}

Keywords: higher education, international students, textual-discursive analysis, ten-stepwise approach

\section{Introduction}

Teaching international tertiary students to analyse how the language of a host country is used in various cultural and social settings of the country that provides educational service is crucially important for their academic and cultural adaptation in a host country (Dorsett, 2017). The analysis of the textual-discursive categories is a component of the studies and social life of the international students in the host country's higher educational institution. That analysis is viewed through both cognitive and social perspectives when the classroom context, in which physical and socio-cultural collaboration takes place, is attempted to be studied (Arvaja, 2008; Plakitsi et al., 2017). Additionally, the recent pandemic caused a shift to the Computer-Supported Collaborative Learning (CSCL) with the instructors' focus on movement from the results of that collaborative work towards the quality of the collaboration processes. From the above perspective, the study is relevant in terms of reshaping international students' training in using and mastering the appropriate thinking-and-acting tools within the educational and cultural settings that exist in a host country society. 


\section{Literature Review}

The theory of social constructivism in education created the framework for the study (Aranguren, 2017; Lynch, 2016). The theory of constructivism at the present stage of development of sociological knowledge makes it possible to objectively cognize reality, in comparison with positivist theories (Taylor, 2018; Clark, 2018). Various discursive practices, actualized by current research, constitute a dynamic aspect of constructivist work, outside other notions that are focused on strategies for modeling the world, ways of thinking. The personality in the perspective of constructivism is analyzed simultaneously as the subject of the transformation of the world, and as its social construct, as a flexible discourse system, is constantly being transformed in the process of social practice (Bozkurt, 2017). The principles and ideas of social constructivism today are the most cited in both educational and scientific and psychological circles. Many modern scholars-reformers base their scientific and intelligence activities on theories of social constructivism. It is very often difficult for students to understand and assimilate the basic principles of social constructivism, as well as to perceive the surrounding reality in line with the tendencies and methodology of social constructivism (Knapp, 2019). Especially when it comes to international students (Havercroft, 2018) in their interaction with the phenomena, objects, realities of political discourse of the host country. Even more in the situation of dominance of online learning of blending learning prevalence when it is necessary to develop theoretical frameworks and models of pedagogical interaction that focuses on the integrated model of pedagogical strategies (Picciano, 2017).

Such a way, the theory of social constructivism in education suggests that both context and situations for the doers of the action and discourse of the latter are socially constructed. The nature of those actions and their discourse are interpretive and the doer shapes and is shaped by the context of them. It means that the context is not determined by the settings or the situation (in this perspective, social constructivism is antithetical to positivist theories of perception of reality). It is flexible and relies on the contextual dimensions that are adjusted to the action or activity (Hajicova, 2013; Pfadenhauer \& Knoblauch, 2018). In the literature, the resources of the context are categorised into immediate and mediated. While the immediate resources guide discourse and shared activity, the mediated ones provide the socio-cultural context to it (Plakitsi et al., 2017). Constructivist approaches have had a significant impact on the global political sphere, offering different theoretical and empirical ideas in explaining global political trends. We are even talking about the growing influence of the ideas of social constructivism on the sphere of international relations (Jung, 2019). However, if global political trends do not pose significant difficulties for foreign students, since the average global trends form a certain more or less unified strategy, then understanding national political discourses taking into account constructivist approaches is real difficulties, especially given the unstable political situation in Ukraine. The above implies that the practice of teaching international students with different social and cultural experiences requires general basic rules for organizing the shared learning activities, thus providing a framework for understanding and creating meaning in the learning situations. It raises the need for teaching international students in political textual-discursive analysis (Koschut, 2020; Benjaminsen \& Svarstad, 2021) so that they could do the collaborative tasks in a university course that are based on communication and interaction with more efficiency.

Therefore, the purpose of the study is to identify how the course that covers the components of the ten-stepwise approach to discourse analysis of political texts helps international students study the political meanings in Ukraine.

\section{Methods and Materials}

The study used the structured observation method to collect rather quantitative than qualitative data and observers' reports on the sampled students' performance in the in-class and out-of-class assignments. It also used discourse analysis awareness test, observation report checklist, and assessment checklist to yield the quantitative data.

\subsection{Research Design}

The study utilised a one-group-only posttest-only quasi-experimental design (Price et al., 2015). Overall, the study lasted from October 2020 until March 2021. It consisted of three basic phases such as the pre-experimental phase that was aimed at developing the concept of the research, designing the textual-discursive analysis course, sampling, and specifying the measurement tools, the intervention phase that attempted to train the international students to discourse analysis, and data analysis phase that presented the output of the study.

\subsection{Textual-discursive Analysis Course Outline}

This was a 1-ECTS course aimed to cover the components of the ten stepwise approach to discourse analysis. It consisted of 7 topics and used the EU Speech database which is available through the link 
https://dataverse.harvard.edu/dataverse/euspeech.Table 1 provides the topics of the course sessions and hours dedicated to them.

Table 1. Topics of the Course Sessions and Hours

\begin{tabular}{clc}
\hline$\#$ & & \multicolumn{1}{c}{ Topic } \\
\hline 1 & Introduction session & Hours \\
2 & Data pre-processing procedures based on the texts from the EU Speech database & 4 \\
3 & Tutor-supervised coding assignments based text research projects (2 projects): Proceeding from text to & 8 \\
& databased on NVivo 12 software tool (Alfasoft, 2021) & 2 \\
4 & Locating the political dimension in the text & 4 \\
5 & Language examination & 2 \\
6 & Group discussion of pros and cons of different approaches to the interpretation of findings & 8 \\
7 & Design the research note of 1500 words & \\
\hline The outline of the ten-stepwise approach to discourse analysis of political texts (adapted from Schneider (2013))
\end{tabular}

The sessions on the pre-processing procedures were conducted as group work in class. These were video-and audio-recorded so that verbal and non-verbal activity of the students such as words, gestures, and mimes could be further described in the observation reports. The data were revealed from the perspective of immediate (perceptual) context, local context, and socio-cultural context (Dremel \& Matić, 2014). The purpose of the above was to identify how the international students interpreted the sources through the preliminary discourse analysis. Overall, the approach is semi-technical because it uses software for assigning codes (themes) to data and systemising them to be further interpreted. The visualised scheme of the approach is presented in Figure 1.

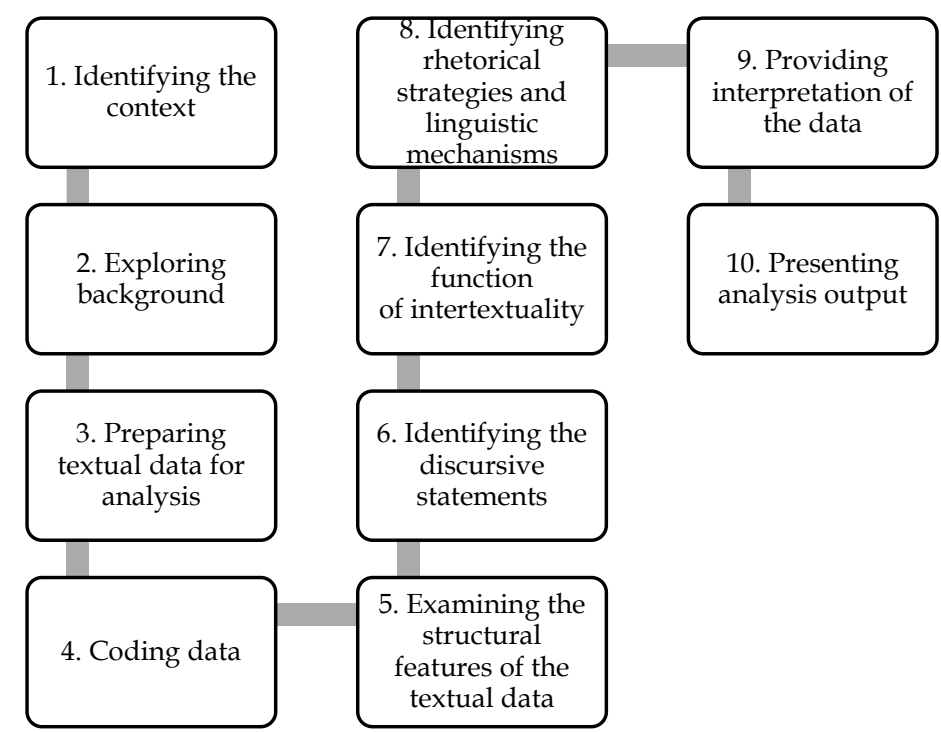

Figure 1. Visualised Scheme of the Ten-Stepwise Approach to Discourse Analysis of Political Text

As can be seen in Figure 1, the discourse analysis process relies on preliminary examination of the textual information, in-depth examination of the data, and interpretation of findings. To elaborate on each step, the discourse analysis starts with identifying the purpose of the discourse analysis and the audience it aims at. The focus of Step 1 is to examine language your source, country, and place it comes from, how it is or was related to the key events, and how the ideas from it were perceived by society. Step 2 concentrates on identifying the producer of the political text, the target audience of the paper, the genre of the text, the position and layout of the text. Any additional features like images or illustrations are also examined because these might shape meaning. Step 3 is related to digitalisation of the source and marking the key details so that it could be easy to process it using software-based tools. Coding data is performed in Step 4. The discourse strands were drawn from the textual data. The step uses the NVivo 12 software tool (Alfasoft, 2021). Step 5 examines the structural features of the textual data (Brun \& Betz, 2016). Its purpose is 
to identify whether there are one or several pieces of discourse in the text and whether the layout of the text guides the argument. Step 6 identifies the macro-features of your text such as the individual statements, or discourse fragments. Step 7 seeks to identify how the context supports or illustrates the argument with the focus on intertextuality. Step 8 examines word groups, grammar features, rhetorical and literary figures, using quotes in the text, modalities, and eventualities (Llorca, 2016). Step 9 is to interpret the data using what you learned about structural features of the text and individual statements and putting them into the wider context. Step 10 attempts to make the findings a convincing case and to present the results of the analysis to the target audience.

\subsection{Sample}

Random sampling was used to hire 287 local students (143 males aged 22-23 and 134 females aged 21-24) majoring in International Economics at Kyiv National Economic University named after Vadym Hetman to pilot the discourse analysis awareness test.

The convenience sampling technique was used to involve 14 students studying a course in Political Economy at Kyiv National Economic University named after Vadym Hetman in the experiment (McCombes, 2021). The reason for using the above sampling technique was that the shared language in that international student group was English. The sampled students formed the experimental group (EG). The demographic features of the group are provided in Table 2.

Table 2. Demographic Features of the Sampled Students

\begin{tabular}{|c|c|c|c|c|c|c|c|c|}
\hline \multicolumn{2}{|c|}{ Demographic features } & \multicolumn{5}{|c|}{ Country of origin } & \multirow[t]{2}{*}{$M$} & \multirow[t]{2}{*}{$S D$} \\
\hline & & AZE & $\mathrm{RDC}$ & NI & TR & UZB & & \\
\hline & & $3(21.42 \%)$ & $2(14.28 \%)$ & $2(14.28 \%)$ & $4(28.57 \%)$ & $3(21.42 \%)$ & 2.80 & 0.748 \\
\hline \multirow[t]{2}{*}{ Gender } & Males & $3(37.50 \%)$ & $0(00.00 \%)$ & $1(12.50 \%)$ & $3(37.50 \%)$ & $1(12.50 \%)$ & 1.60 & 1.200 \\
\hline & Females & $0(00.00 \%)$ & $2(33.33 \%)$ & $1(16.66 \%)$ & $1(16.66 \%)$ & $2(33.33 \%)$ & 1.20 & 0.748 \\
\hline \multirow[t]{3}{*}{ Age } & $20-24$ & $2(33.33 \%)$ & $1(16.66 \%)$ & $1(16.66 \%)$ & $1(16.66 \%)$ & $1(16.66 \%)$ & 1.20 & 0.400 \\
\hline & $25-30$ & $0(00.00 \%)$ & $1(20.00 \%)$ & $1(20.00 \%)$ & $2(40.00 \%)$ & $1(20.00 \%)$ & 1.00 & 0.632 \\
\hline & $31-35$ & $1(33.33 \%)$ & $0(00.00 \%)$ & $0(00.00 \%)$ & $1(33.33 \%)$ & $1(33.33 \%)$ & 0.60 & 0.489 \\
\hline G.P.A. & & 2.0 & 3.0 & 2.7 & 2.3 & 2.3 & 2.46 & 0.349 \\
\hline
\end{tabular}

Note: AZE - Azerbaijan; RDC - Congo; NI - Nigeria; TR - Turkey; UZB - Uzbekistan; G.P.A. - Grade Point Average; G.P.A values of 2.0 are equal to C (73-76 ECTS), $2.3=\mathrm{C}+(77-79 \mathrm{ECTS}), 2.7=\mathrm{B}(80-82$ ECTS $), 3.0=\mathrm{B}$ (83-86 ECTS) (wiki How's Content Management Team, 2021).

\subsection{Instruments}

Three instruments were used to collect descriptive data for the study. These were as follows: discourse analysis awareness test (Appendix A), (based on Cornish, 2009; BBC, 2021) (Available at: https://forms.gle/Ya5KDtRar3hjxksi7), the observation report checklist (Appendix B), and assessment checklist to assess EG students' research notes (Appendix C). The Voyant Tools software was used to analyse the text corpus of the observer's reports (Sinclair \& Rockwell, 2003). The data yielded from the assessment checklist (Appendix C) were process sedusing the Jamovi Project (2021) Computer Software (Version 1.8.1).

Discourse analysis awareness test (Appendix A), (based on Cornish, 2009; BBC, 2021) (Available at: https://forms.gle/Ya5KDtRar3hjxksi7)

The test was designed to cover the basics of the discourse analysis of a text and was administered to the EG students online. It included 10 multiple-choice questions. Each correct answer scored two grades. The test was piloted before it was used in the study. In this phase, the reliability and validity of test scores were assessed using the methods of differential item functioning (DIF) and differential test functioning (DTF). The results of the DIF analysis are presented in Table 3. 
Table 3. Results of DIF Analysis

\begin{tabular}{ccc}
\hline Question & Statistics & $\mathrm{p}$-value \\
\hline Q1 & 1.48 & 0.522 \\
Q2 & 1.08 & 0.981 \\
Q3 & 2.51 & 0.439 \\
Q4 & 1.65 & 0.658 \\
Q5 & 1.37 & 0.929 \\
Q6 & 2.55 & 0.255 \\
Q7 & 3.91 & 0.283 \\
Q8 & 4.16 & 0.064 \\
Q9 & 3.32 & 0.237 \\
Q10 & 4.71 & 0.049 \\
\hline
\end{tabular}

As can be seen in Table 1, no inconsistency was detected in the test. The values for the items were within the reference limits. The value for the results of correlation (r) between the answered and unanswered questions of the test was 0.8138 ( $\mathrm{p}$-value $=<.001 ; \mathrm{p}<.05)$. It meant that the answered and unanswered questions were related well. The results of the Mantel-Haenszel/Liu-Agresti differential test functioning (DTF) method are presented in Table 4.

Table 4. The Entire Test DTF Results

\begin{tabular}{ccccc}
\hline Test-All & Statistics & Value & SE & Z \\
\cline { 2 - 5 } & $t^{2}$ & 0.065 & 0.012 & 5.667 \\
& Weighted $t^{2}$ & 0.06 & 0.01 & 6.000 \\
\hline
\end{tabular}

As can be seen in Table 3, the value for the DTF variance is lower than $0.07\left(t^{\wedge} 2=0.065\right)$ which indicates that the DTF effect of the test is small (Penfield, 2013). This suggested that the test could be used in the intervention and could be considered reliable and valid.

\subsection{Observation Report Checklist (Appendix B)}

The observation report checklist included six items that covered students' involvement and performance while they were doing the discourse analysis of the texts within the class settings. It used 5-point Likert scale with 1 meaning poor; 2 = Fair;3 = Good; $4=$ Very Good; $5=$ Excellent. Seven experts (three experts with a Ph.D. degree in Pedagogics, and four experts with a Ph.D. degree in Philology) were hired to evaluate the face and content validity, reliability, and construct validity of it. The item-level content validity index (IL-CVI) was higher than 0.86 and the Kappa coefficient was greater than 0.83 . Those values meant a 'good validity' (Costa et al., 2019).

\subsection{Assessment Checklist to Assess EG Students'Research Notes (Appendix C)}

The checklist relied on 5 items and the 5-point Harvard performance rating scale with 5 meaning FE (Far Exceeds), 4 = EX (Exceeds Expectations), $3=\mathrm{ME}$ (Meets Expectations), $2=\mathrm{DR}$ (Development Required), and $1=\mathrm{IR}$ (Improvement Required). Seven experts (four experts with a Ph.D. degree in Pedagogics, and three experts with a $\mathrm{Ph} . \mathrm{D}$. degree in Psychology) were also hired to evaluate the face and content validity, reliability, and construct validity of it. The item-level content validity index (IL-CVI) was higher than 0.88 and the Kappa coefficient was greater than 0.85 . Those values meant a 'good validity' (Costa et al., 2019).

\section{Results}

The study found that the course that is based on teaching international students in the use of a ten-stepwise approach to discourse analysis of political texts raises the students' overall awareness of analysis of textual-discursive categories and fosters students' skills of the analysis of textual-discursive categories of those texts. The quantitative data drawn from the discourse analysis awareness test and assessment checklist, along with the qualitative data yielded from the observation reports are presented below.

\subsection{Results of the Discourse Analysis Awareness Test}

The results of the test presented in Table 5 suggested that the EG students' awareness of discourse analysis was generally good. As can be seen in Table, the mean values varied between 0.643 and 0.857 which corresponded to 
65-85 grades ECTS.

Table 5. Descriptive Statistics Obtained from the Discourse Analysis Awareness Test

\begin{tabular}{|c|c|c|c|c|c|c|c|c|c|c|}
\hline & \multirow[t]{2}{*}{ Mean } & \multicolumn{2}{|c|}{$\begin{array}{c}95 \% \text { Confidence } \\
\text { Interval } \\
\end{array}$} & \multirow[t]{2}{*}{ SD } & \multicolumn{2}{|c|}{ Skewness } & \multicolumn{2}{|c|}{ Kurtosis } & \multicolumn{2}{|c|}{ Shapiro-Wilk } \\
\hline & & Lower & Upper & & Skewness & SE & Kurtosis & SE & $\mathrm{W}$ & $\mathrm{p}$ \\
\hline $\mathrm{q} 1$ & 0.857 & 0.667 & 1.047 & 0.363 & -0.295 & 0.597 & 0.792 & 1.15 & 0.928 & $<.001$ \\
\hline $\mathrm{q} 2$ & 0.786 & 0.563 & 1.009 & 0.426 & -0.566 & 0.597 & 0.501 & 1.15 & 0.816 & $<.001$ \\
\hline $\mathrm{q} 3$ & 0.786 & 0.563 & 1.009 & 0.426 & -0.566 & 0.597 & 0.501 & 1.15 & 0.916 & $<.001$ \\
\hline $\mathrm{q} 4$ & 0.857 & 0.667 & 1.047 & 0.363 & -0.295 & 0.597 & 0.792 & 1.15 & 0.928 & $<.001$ \\
\hline q5 & 0.786 & 0.563 & 1.009 & 0.426 & -0.566 & 0.597 & 0.501 & 1.15 & 0.916 & $<.001$ \\
\hline q6 & 0.786 & 0.563 & 1.009 & 0.426 & -0.566 & 0.597 & 0.501 & 1.15 & 0.916 & $<.001$ \\
\hline $\mathrm{q} 7$ & 0.643 & 0.382 & 0.903 & 0.497 & -0.370 & 0.597 & -0.838 & 1.15 & 0.816 & $<.001$ \\
\hline q8 & 0.714 & 0.469 & 0.960 & 0.469 & -0.067 & 0.597 & -0.034 & 1.15 & 0.876 & $<.001$ \\
\hline q9 & 0.857 & 0.667 & 1.047 & 0.363 & -0.295 & 0.597 & 0.792 & 1.15 & 0.928 & $<.001$ \\
\hline $\mathrm{q} 10$ & 0.786 & 0.563 & 1.009 & 0.426 & -0.566 & 0.597 & 0.501 & 1.15 & 0.916 & $<.001$ \\
\hline
\end{tabular}

Further to the above, the values for Skewness, Kurtosis, and Shapiro-Wilkwere close to zero which meant good normal distribution of the variable. Additionally, those values of the study sample indicated that the distribution is likely to be also normal for a wider population of international students.

\subsection{The Findings from the Observation Reports}

The reports of seven experts (three experts with a Ph.D. degree in Pedagogics, and four experts with a Ph.D. degree in Philology) were consolidated in plain text and analysed using the Voyant Tools software (Sinclair \& Rockwell, 2003). The five most frequent words used in the corpus were as follows: students, contributed, equally, succeeded, managed. All of them evoke a positive idea and feeling and reveal success in meeting goals.

The most frequent collocations with strong correlations were as follows: 'students-coding' ( $\mathrm{r}=1)$, 'students-contributed' $\quad(\mathrm{r}=0.9688), \quad$ students-progressed $\quad(\mathrm{r}=0.9593), \quad$ 'contributed-activity' $\quad(\mathrm{r}=0.9512)$, 'contributed-equally' $\quad(\mathrm{r}=0.9429), \quad$ 'equally-managed' $\quad(\mathrm{r}=0.9322) \quad$ 'equally-collaborated' $\quad(\mathrm{r}=0.9301)$, 'succeeded-coding' $\quad(\mathrm{r}=0.9277), \quad$ 'succeeded-analysis' $\quad(\mathrm{r}=0.9251) \quad$ 'managed-strategies' $\quad(\mathrm{r}=0.9119)$, 'managed-discourse' ( $\mathrm{r}=0.9091$ ) (see Figure 2).

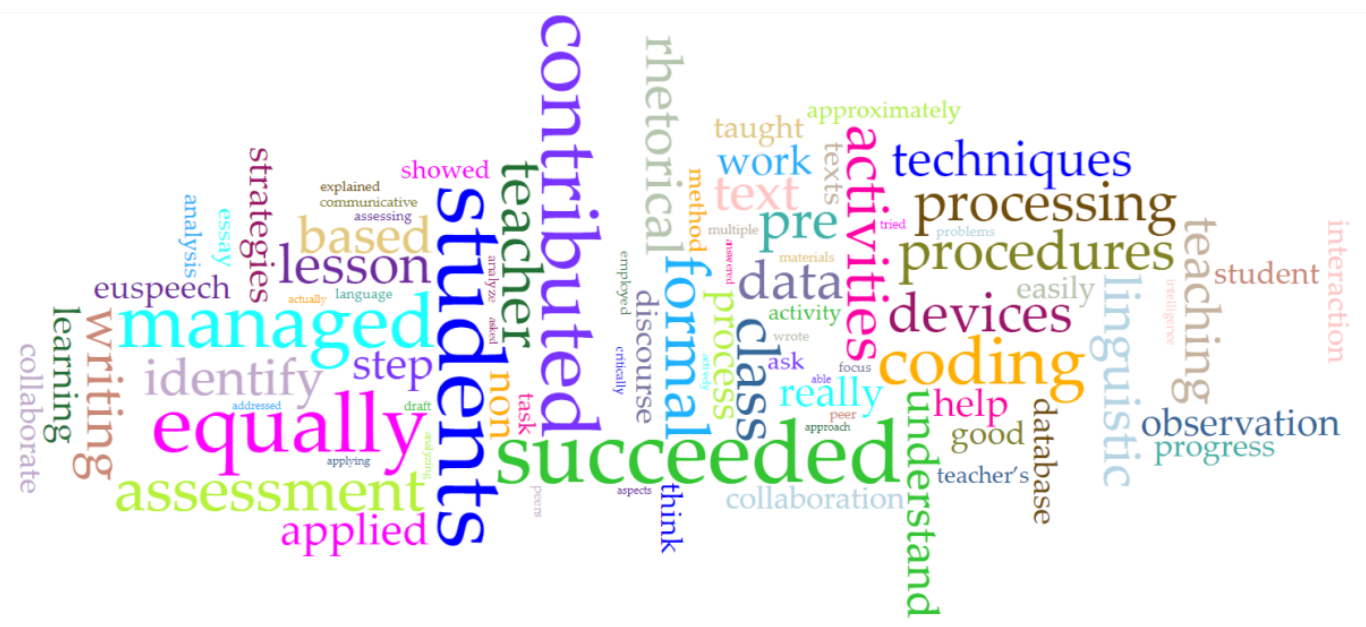

Figure 2. Word Cloud That Rates the Use of the Keywords in the Observation Reports

The themes that were covered by the experts were as follows: learning engagement, male-female interaction, coding, linguistic analysis, and presentation. Table 6 provides some quotes that were extracted from the reports and 
categorised under the appropriate theme.

Table 6. Theme and Quotes Drawn from the Observation Reports

\begin{tabular}{|c|c|}
\hline Theme & Quote \\
\hline Learning engagement & $\begin{array}{l}\text { '...different pedagogic means were used ... to involve the students in the interaction and } \\
\text { collaboration...' } \\
\text { '... the efficiency of collaborate work was sufficient ...' }\end{array}$ \\
\hline Male-female interaction & $\begin{array}{l}\text { '... male students and female ones were doing some activities separately to avoid confrontation of } \\
\text { the latter...' } \\
\text { '... sometimes female students' opinion was taken by the male students arrogantly... it was an } \\
\text { issue for the teacher ...' } \\
\text { '... male students thought that politics is not for women...' }\end{array}$ \\
\hline Coding & $\begin{array}{l}\text { '...this was the most challenging task... for both genders ...' } \\
\text { '....students needed additional stimulus when doing the projects on coding...' }\end{array}$ \\
\hline Linguistic analysis & $\begin{array}{l}\text { '... students managed to perform the analysis after several attempts...' } \\
\text { '... Ss needed personalized assistants in doing linguistic analysis activities ...' }\end{array}$ \\
\hline Presentation & $\begin{array}{l}\text { '... provided students with the experience of meeting challenges ...' } \\
\text { '... students encouraged each other in presentations ...' }\end{array}$ \\
\hline
\end{tabular}

The quotes in Table 6 imply that the course sessions were engaging, challenging, and fruitful in terms of learning how to analyze textual-discursive categories found in political texts. The descriptive statistics drawn from the observation checklist and presented by course topic are provided in Table 7.

Table 7. Descriptive Statistics Drawn from the Observation Checklist and Presented by Course Topic

\begin{tabular}{|c|c|c|c|c|c|c|c|}
\hline & Topic 1 & Topic 2 & Topic 3 & Topic 4 & Topic 5 & Topic 6 & Topic 7 \\
\hline Mean & 2.54 & 3.11 & 3.37 & 3.92 & 4.23 & 4.41 & 4.58 \\
\hline Std. error mean & 0.105 & 0.121 & 0.223 & 0.132 & 0.156 & 0.133 & 0.148 \\
\hline SD & 0.548 & 0.603 & 0.618 & 0.539 & 0.551 & 0.662 & 0.684 \\
\hline$\sigma$ & 0.484 & 0.398 & 0.553 & 0.497 & 0.329 & 0.449 & 0.338 \\
\hline $\begin{array}{l}\text { Shapiro-Wilk W } \\
\text { (p) }\end{array}$ & $\begin{array}{c}0.839 \\
(<.001)\end{array}$ & $\begin{array}{c}0.894 \\
(<.001)\end{array}$ & $\begin{array}{c}0.867 \\
(<.001)\end{array}$ & $\begin{array}{c}0.833 \\
(<.001)\end{array}$ & $\begin{array}{c}0.864 \\
(<.001)\end{array}$ & $\begin{array}{c}0.876 \\
(<.001)\end{array}$ & $\begin{array}{c}0.875 \\
(<.001)\end{array}$ \\
\hline
\end{tabular}

As can be seen in Table 7, the observers' mean values improved throughout the course sessions that meant that the students progressed in the discourse analysis.

\subsection{Results Based on the Assessment Checklist to Assess EG Students'Research Notes}

The EG students' research notes were assessed by three research team members that used the checklist. The descriptive statistics of the assessment are presented in Table 8.

Table 8. Descriptive Statistics of the Assessment of the EG Students' Research Notes

\begin{tabular}{lccc}
\hline & Assessor 1 & Assessor 2 & Assessor 3 \\
\hline Mean & 3.95 & 4.22 & 4.06 \\
SD & 0.782 & 0.831 & 0.804 \\
Shapiro-Wilk W (p) & $0.911(<.001)$ & $0.942(<.001)$ & $0.931(<.001)$ \\
\hline
\end{tabular}

As can be seen from Table 8 , the assessors rated the students' research notes as those that either meet expectations or exceed expectations, which were also considered a positive outcome of the course. 
The results of the experimental part of the research proves that the social and constructive approach comes from the fact that political, political economical and generally all social events, processes and changes are always associated with the language (semiotics), therefore, to study them comprehensively, a "turn" is needed towards the discourse. The developed diagnostic model and the results also proved that cultural approach to the analysis of discourses denies the possibility of a universal methodology's presence, as each political discourse has its own cultural, historical and linguistic traditions that have to be shifted and adopted while changing the country of living. As we have in the current situation dealing with international students. The qualitative analisys of the results demonstrated that along with the discourse, a culture becomes a second key concept in this approach. In the descriptive approach, it is primarily about the form of language use, so linguistic methods of interpretation of texts dominated here. Morphological (structural) descriptions allows studying discourse at several levels from the point of view of various linguistic units, patterns and relations between them. A functional analysis of discourse explores its relationship with cognitive, social and cultural contexts. The hermeneutics emphasizes the role of a subject in interpretation and includes personal experience and sense of researcher in the analysis process.

\subsection{Limitations}

The limitations of the study can be as follows: the sample size, the sampling technique, the involvement of only one institution in the experiment, and the data drawn from observations.

\section{Discussion}

The study attempted to identify how the course that covers the components of the ten-stepwise approach to discourse analysis of political texts helps international students study the political meanings in Ukraine. The novelty of this attempt is in the design and piloting of the discourse analysis awareness test and design of the textual-discursive analysis course that develops both international students' skills of the discourse analysis and their technical skills to use the NVivo 12 software tool.

It was found that the course that is based on teaching international students in the use of a ten-stepwise approach to discourse analysis of political texts raises the students' overall awareness of analysis of textual-discursive categories and fosters students' skills of the analysis of textual-discursive categories of those texts.

The results of the discourse analysis awareness test suggested that the EG students' awareness of discourse analysis was generally good. The mean values varied between 0.643 and 0.857 , which corresponded to $65-85$ grades ECTS. Further to the above, the values for Skewness, Kurtosis, and Shapiro-Wilk were close to zero, which meant good normal distribution of the variable. Additionally, those values of the study sample indicated that the distribution is likely to be also normal for a wider population of international students.

The analysis of the observation reports showed that the five most frequent words used in the corpus of the observation reports of seven experts were as follows: students, contributed, equally, succeeded, managed. All of them evoke a positive idea and feeling and reveal success in meeting goals. The most frequent collocations with strong correlations were as follows: 'students-coding' $(\mathrm{r}=1)$, 'students-contributed' $(\mathrm{r}=0.9688)$, students-progressed ( $\mathrm{r}=0.9593)$, 'contributed-activity' $(\mathrm{r}=0.9512)$, 'contributed-equally' $(\mathrm{r}=0.9429)$, 'equally-managed' $(\mathrm{r}=0.9322)$ 'equally-collaborated' $\quad(\mathrm{r}=0.9301), \quad$ 'succeeded-coding' $\quad(\mathrm{r}=0.9277), \quad$ 'succeeded-analysis' $\quad(\mathrm{r}=0.9251)$ 'managed-strategies' ( $\mathrm{r}=0.9119)$, 'managed-discourse' ( $\mathrm{r}=0.9091)$.

The themes that were covered by the experts were as follows: learning engagement, male-female interaction, coding, linguistic analysis, and presentation. The quotes yielded from the reports implied that the course sessions were engaging, challenging, and fruitful in terms of learning how to analyze textual-discursive categories found in political texts. The descriptive statistics drawn from the observation checklist and presented by course topic showed that the observers' mean values improved throughout the course sessions that meant that the students progressed in the discourse analysis.

The descriptive statistics of the assessment of the EG students' research notes showed that these were rated as those that either meet expectations or exceed expectations which also suggested that the course enriched the EG students' experience and knowledge of discourse analysis.

The findings agree with the previous research. It agrees with the concept of the critical discourse analysis and the ten-stepwise approach to discourse analysis of political texts fits that field (Hernández-Guerra, 2014). The analysis is aimed at examining the implied content in a text to identify the ideological bias, which is seen as implicit assumptions. The study goes in line with the approach to discourse analysis suggested by Rehner (2017). It agrees 
with Sengul (2019) who states that teaching discourse analysis at universities is useful for the students in terms of understanding the complexity of political communication in the media. The study supports the findings on teaching the discourse analysis of political texts to international students produced by Yi and Jung (2015) who revealed that it helps those students to tolerate the attempts of western and American politicians to promote the ideas of white and elite dominance. It goes in line with Alsoraihi (2019) who found that teaching students discourse analysis improves the quality of language learning techniques, quality of communication in the class because students use their linguistic knowledge in social and cultural contexts.

\section{Conclusion}

The course that is based on the ten-step-wise approach to discourse analysis of political texts proved to raise the students' overall awareness of analysis of textual-discursive categories and fosters their skills of both discourse analysis and technical skills to use the NVivo 12 software tool. The results of the discourse analysis awareness test showed that the sampled students' awareness of discourse analysis was generally good. The mean values varied between 0.643 and 0.857 , which corresponded to $65-85$ grades ECTS. The analysis of the observation reports showed that the five most frequent words used in the corpus of the observation reports of seven experts were as follows: students, contributed, equally, succeeded, managed. All of them evoke a positive idea and feeling and reveal success in meeting goals. The most frequent collocations with strong correlations were as follows: 'students-coding', 'students-contributed', students-progressed, 'contributed-activity', 'contributed-equally', 'equally-managed', 'equally-collaborated', 'succeeded-coding', 'succeeded-analysis', 'managed-strategies', 'managed-discourse'. The quotes yielded from the reports implied that the course sessions were engaging, challenging, and fruitful in terms of learning how to analyze textual-discursive categories found in political texts. The descriptive statistics drawn from the observation checklist and presented by course topic showed that the observers' mean values improved throughout the course sessions that meant that the students progressed in the discourse analysis.

\subsection{Recommendation}

It would be desired if the practitioners addressed the gender issues in the groups of international students who belong to Muslim confession. The practitioners are also supposed to tolerate any inadequate reactions regarding gender issues. It is welcomed if the lecturer for the group of international students could be a male.

\section{Acknowledgement}

We are grateful to the experts for providing an assessment of the research instruments. We are also grateful to the sampled students for the commitment and patience that they showed while taking part in the course.

\section{Conflicts of Interest}

No conflicts of interest related to the authors' affiliation, or legal, financial, commercial origin are declared by authors.

\section{References}

Alfasoft. (2021). NVivo 12 software. Retrieved from https://www.alfasoft.com/en/

Alsoraihi, M. H. (2019). Bridging the gap between discourse analysis and language classroom practice. English Language Teaching, 12(8), 79-88. https://doi.org/10.5539/elt.v12n8p79

Aranguren, M. (2017). Reconstructing the social constructionist view of emotions: from language to culture, including nonhuman culture. Journal for the Theory of Social Behaviour, 47(2), 244-260. https://doi.org/10.1111/jtsb.12132

Arvaja, M. (2008). Discursive approach for studying contexts in students' collaborative activity. In Proceedings of the 8th international conference on International conference for the learning sciences, Vol.1 (ICLS'08). International Society of the Learning Sciences, 52-59. Retrieved from https://dl.acm.org/doi/proceedings/10.5555/1599812

BBC. (2021). Language and structure. Bitesize. Retrieved from https://www.bbc.co.uk/bitesize/guides/zq6vg82/test 
Benjaminsen, T. A., \& Svarstad, H. (2021). Discourses and narratives on environment and development: The example of bioprospecting. In T. A. Benjaminsen \& H. Svarstad (Eds.), Political Ecology (pp. 59-87). Cham: Palgrave Macmillan. https://doi.org/10.1007/978-3-030-56036-2_3

Bozkurt, G. (2017). Social Constructivism: Does It Succeed in Reconciling Individual Cognition with Social Teaching and Learning Practices in Mathematics? Journal of Education and Practice, 8(3), 210-218.

Brun, G., \& Betz, G. (2016). Analysing Practical Argumentation. In: Hansson, S., Hirsch Hadorn, G. (Eds.), The Argumentative Turn in Policy Analysis. Logic, Argumentation \& Reasoning (Interdisciplinary Perspectives from the Humanities and Social Sciences), vol 10. New York: Springer. https://doi.org/10.1007/978-3-319-30549-3_3

Clark, K. R. (2018). Learning theories: constructivism. Radiologic Technology, 90, 180-182.

Cornish, F. (2009). "Text" and "discourse" as "context": Discourse anaphora and the FDG Contextual component. Working Papers in Functional Discourse Grammar (WP-FDG-82), The London Papers I, 1(1), 97-115. Retrieved from https://hal-univ-tlse2.archives-ouvertes.fr/hal-00961139

Costa, R. Z. F., Medina-Papst, J., Spinosa, R. M. de O., Santo, D. L., \& Marques, I. (2019). Content validity, reliability, and construct validity of a checklist for dive roll evaluation. Journal of Physical Education, 30, e3054. https://dx.doi.org/10.4025/jphyseduc.v30i1.3054

Dorsett, J. (2017). Exploring international student adaptation through a first-year experience course at Iowa State University [PhD Dissertation Thesis]. Iowa State University. Iowa State UniversityDigital Repository. Retrieved from https://lib.dr.iastate.edu/etd/15296

Dremel, A., \& Matić, R. (2014). Discourse and/as Social Practice - the Analysis of the Problem of Resistance and Hegemony. Mediterranean Journal of Social Sciences, 155. https://doi.org/10.5901/mjss.2014.v5n22p155

Hajicova, E. (2013). Contextual boundness and discourse patterns revisited. Discourse Studies, 15(5), 535-550. https://doi.org/10.1177/1461445613501445

Havercroft, J. (2018). Social Constructivism and International Ethics. In: B. J. Steele, E. A. Heinze (Eds.), Routledge Handbook on Ethics in International Relations (pp.116-129). London: Routledge. https://doi.org/10.4324/9781315725932-11

Hernández-Guerra, C. (2014). An overview of the approaches and methods for analysing a text from a discursive viewpoint. Onomázein, 30, 237-246. https://doi.org/10.7764/onomazein.30.17

Jung, H. (2019). The evolution of social constructivism in political science: past to present. SAGE Open, 9(1), 2158244019832703. https://doi.org/10.1177\%2F2158244019832703

Knapp, N. F. (2019). The shape activity: Social constructivism in the psychology classroom. Teaching of Psychology, 46(1), 87-91. https://doi.org/10.1177\%2F0098628318816181

Koschut, S. (2020). Emotion, discourse, and power in world politics. In The Power of emotions in world politics (pp. 3-28). London: Routledge. https://doi.org/10.4324/9780429331220-2

Llorca, C. M. (2016). Rhetorical strategies in discourses about language: the persuasive resources of ethos. Res Rhetorica, 3(1), 68-89. https://doi.org/10.17380/rr2016.1.5.

Lynch, M. (2016). Social constructivism in education. The Edvocate. Retrieved from https://www.theedadvocate.org/social-constructivism-in-education/

McCombes, S. (2021). An introduction to sampling methods. Scribbr. https://www.scribbr.com/methodology/sampling-methods/

Penfield, R. (2013). DIFAS 5.0: Differential item functions analysis system. User's manual. Retrieved from https://soe.uncg.edu/wp-content/uploads/2015/12/DIFASManual_V5.pdf

Pfadenhauer, M., \& Knoblauch, H. (Eds.). (2018). Social Constructivism as Paradigm?: The Legacy of The Social Construction of Reality. London: Routledge. https://doi.org/10.4324/9780429467714

Picciano, A. G. (2017). Theories and frameworks for online education: Seeking an integrated model. Online Learning, 21(3), 166-190. https://doi.org/10.24059/olj.v21i3.1225

Plakitsi, K., Piliouras, P., \& George, E. (2017). Discourse Analysis: A Tool for Helping Educators to Teach Science [82 paragraphs]. Forum Qualitative Sozialforschung / Forum: Qualitative Social Research, 18(1), Art. 6. 
Retrieved from http://nbn-resolving.de/urn:nbn:de:0114-fqs170168.

Price, P., Jhangiani, R., \& Chiang, I. (2015). Research Methods in Psychology - 2nd Canadian Edition. Retrieved from https://opentextbc.ca/researchmethods/

Rehner, K. (2017). An introduction to discourse analysis. SAGE Research Methods Video. Retrieved from https://www.doi.org/10.4135/9781473991859

Schneider, F. (2013). How to do discourse analysis. Politics EastAsia. Retrieved from http://www.politicseastasia.com/studying/how-to-do-a-discourse-analysis/

Sengul, K. (2019). Critical discourse analysis in political communication research: a case study of right-wing populist discourse in Australia. Communication Research and Practice. Oxfordshire: Routledge. https://doi.org/10.1080/22041451.2019.1695082

Sinclair, S., \& Rockwell, G. (2003). Voyant Tools. Retrieved from https://voyant-tools.org/

Taylor, S. P. (2018). Critical realism vs social constructionism \& social constructivism: application to a social housing research study. International Journal of Sciences: Basic and Applied Research, 37(2), 216-222.

The jamovi project. (2021). jamovi. (Version 1.8.1) [Computer Software]. Retrieved from https://www.jamovi.org

Wiki How's Content Management Team. (2021). How to convert a percentage into a 4.0 Grade Point Average. wikiHow. Retrieved from https://www.wikihow.com/Convert-a-Percentage-into-a-4.0-Grade-Point-Average

Yi, J. E., \& Jung, G. (2015). Public discourses about international students. Sociology Compass, 9(9), 776-783. https://doi.org/10.1111/soc4.12293

\section{Appendix A}

\section{Discourse analysis awareness test (based on Cornish, 2009; BBC, 2021)}

(Available at: https://forms.gle/Ya5KDtRar3hjxksi7)

1) The text is

a) a written message

b) the piece of at least one utterance act

c) connected sequences of signs and signals corresponding to contextualization cues

d) answers b and c.

2) The context of a text is

a) mutual personal knowledge

b) the socio-cultural environment which the text takes as fact

c) given act of utterance making the surrounding co-text

d) general writer's encyclopedic and cultural knowledge.

3) The discourse is

a) the hierarchically structured acts that make the mentally represented product of the sequence of utterance, propositional, illocutionary, and indexical acts

b) constructed by the communicator model of the communicative event

c) provisional and revisable interpretation of the communicative event

d) relative degrees of topicality.

4) The language within writing is referred to as

a) literary devices that the writer has used (similes, metaphors) or words that carry connotations for the reader 
b) the text components such as introduction, body, and conclusion

c) parts of speech

d) all the above.

5) A connotation is

a) a set of descriptive words that explain the text

b) vocabulary that is used to create long, descriptive sentences

c) the connectors that are used to link the words of sentences

d) links or associations that the reader makes with a particular word.

6) The structure can show direction within writing through

a) numbering the paragraphs so that the reader could easily follow the idea when they annotate

b) highlighting the sections of the text with different colours

c) using bold fonts

d) the use of linking words.

7) Structuring ideas or events in political texts can be performed via

a) using specific text layout

b) first, putting the key information at the start, and second, reverse back to show what happened

c) using bold fonts

d) using headings and sub-headings

8) TAP stands for

a) Text, advice, priority

b) Text type, audience, purpose

c) Text, advise, purpose

d) Topic, audience, purpose

9) The tone within a text is identified with

a) the level of formality the writer uses to express their views

b) difficulty of the vocabulary

c) the way that the text is structured on the page

d) the layout of the text.

10) The persuasion purpose of the text is indicated by

a) the focus on the pros and cons of something

b) the use of persuasive techniques and functional language

c) bright colours to highlight information

d) the capitalized font and laid out in paragraphs.

Note: Answer key: 1d; 2b; 3a; 4a; 5d; 6a; 7b; 8b; 9c; 10a 


\section{Appendix B}

Observation report checklist

\begin{tabular}{|c|c|c|c|c|c|c|}
\hline \multirow[t]{2}{*}{ \# } & \multirow[t]{2}{*}{ Item } & \multicolumn{5}{|c|}{ Likert quality scale } \\
\hline & & 1 & 2 & 3 & 4 & 5 \\
\hline 1 & Students contributed to the activities approximately equally & & & & & \\
\hline 2 & Males dominated in the interpretations over females & & & & & \\
\hline 3 & $\begin{array}{l}\text { The resources from the EU Speech database mediated the student discourse and their } \\
\text { activity }\end{array}$ & & & & & \\
\hline 4 & Students succeeded in coding using the NVivo 12 software tool & & & & & \\
\hline 5 & Students managed to identify rhetorical and linguistic devices in the text & & & & & \\
\hline 6 & Students presentations of their discourse analysis findings were up to standard & & & & & \\
\hline
\end{tabular}

Note: 1 = Poor; 2 = Fair; 3 = Good; 4 = Very Good; 5 = Excellent.

\section{Copyrights}

Copyright for this article is retained by the author(s), with first publication rights granted to the journal.

This is an open-access article distributed under the terms and conditions of the Creative Commons Attribution license (http://creativecommons.org/licenses/by/4.0/). 